\title{
Feeding at the front line: interannual variation in the use of glacier fronts by foraging black-legged kittiwakes
}

\author{
Philip Bertrand ${ }^{1,2, *}$, Hallvard Strøm ${ }^{2}$, Joël Bêty ${ }^{1}$, Harald Steen ${ }^{2}$, Jack Kohler ${ }^{2}$, \\ Mikko Vihtakari ${ }^{3}$, Ward van Pelt ${ }^{4}$, Nigel Gilles Yoccoz ${ }^{5}$, Haakon Hop ${ }^{2}$, \\ Stephanie M. Harris ${ }^{6,7}$, Samantha C. Patrick ${ }^{7}$, Philipp Assmy ${ }^{2}$, Anette Wold ${ }^{2}$, \\ Pedro Duarte ${ }^{2}$, Geir Moholdt ${ }^{2}$, Sébastien Descamps ${ }^{2}$ \\ ${ }^{1}$ Départment de Biologie, Chimie et Géographie and Centre d'Études Nordiques, Université du Québec à Rimouski, \\ Rimouski, QC G5L 3A1, Canada \\ ${ }^{2}$ Norwegian Polar Institute, Fram Centre, Tromsø 9296, Norway \\ ${ }^{3}$ Institute of Marine Research, Fram Centre, Tromsø 9296, Norway \\ ${ }^{4}$ Department of Earth Sciences, Uppsala University, Uppsala 752 36, Sweden \\ ${ }^{5}$ Department of Arctic and Marine Biology, UiT The Arctic University of Norway, Tromsø 9037, Norway \\ ${ }^{6}$ Cornell Lab of Ornithology, Cornell University, 159 Sapsucker Woods Road, Ithaca, NY 14850, USA \\ ${ }^{7}$ School of Environmental Sciences, University of Liverpool, Liverpool L3 5DA, UK
}

\begin{abstract}
Tidewater glacier fronts can represent important foraging areas for Arctic predators. Their ecological importance is likely to change in a warmer Arctic. Their profitability and use by consumers are expected to vary in time, but the underlying mechanisms driving such variation remain poorly known. The subglacial plume, originating from meltwater discharge, is responsible for the entrainment and transport of zooplankton to the surface, making them more readily available for surface-feeding seabirds. Both discharge and zooplankton abundance are known to fluctuate in time and are thus expected to modulate the foraging profitability of glacier fronts. This study tested the predictions that annual use of glacier fronts by black-legged kittiwakes Rissa tridactyla is positively related to the average glacier discharge and prey biomass in the fjord. To do this, we combined a multiyear dataset of environmental drivers and GPS tracks of birds in Kongsfjorden, Svalbard. Our results confirmed the interannual variation in the use of glacier fronts by kittiwakes; however, contrary to our predictions, these variations were negatively correlated to both glacier discharge and zooplankton abundance. These apparent negative relationships likely reflect non-linear effects and complex interactions between local and regional environmental factors that affect the relative profitability of glacier fronts as foraging areas. Despite their high spatial predictability, glacier fronts may not offer consistent foraging opportunities for marine predators over time.
\end{abstract}

KEY WORDS: Tidewater glacier front $\cdot$ Habitat selection $\cdot$ Profitability $\cdot$ Discharge $\cdot$ Zooplankton biomass $\cdot$ Rissa tridactyla $\cdot$ Biologging

\section{INTRODUCTION}

Tidewater glacier fronts have for a long time been viewed as important foraging areas for Arctic wildlife (Hartley \& Fisher 1936, Stott 1936). Several studies

\footnotetext{
${ }^{*}$ Corresponding author: philip.bertrand@uqar.ca
}

have highlighted the potential ecological importance of these ice-associated foraging habitats for bird and mammal species in a warming Arctic (Lydersen et al. 2014, Grémillet et al. 2015, Dalpadado et al. 2016, Hamilton et al. 2019). Despite the reported negative

() The authors 2021. Open Access under Creative Commons by Attribution Licence. Use, distribution and reproduction are unrestricted. Authors and original publication must be credited. 
impacts of temperature increases on Arctic ecosystems (Post et al. 2013, AMAP 2017), faster melting of tidewater glaciers might, counterintuitively, increase their ecological importance until the glacier fronts retreat onto land (Lydersen et al. 2014, Grémillet et al. 2015, Meire et al. 2017, Hopwood et al. 2020). Recent evidence suggests that their profitability as foraging habitats might vary among years (Hamilton et al. 2017, Stempniewicz et al. 2017, 2021, Dragańska-Deja et al. 2020). Yet, drivers of such variability are poorly known, and the use of glacier fronts by wildlife should ultimately depend on their relative profitability in relation to alternative foraging habitats. Untangling the environmental drivers of glacier front use and profitability should help to assess the relative importance of these spatially restricted habitats in the context of global warming.

Subglacial plumes are major components of these coastal habitats and have been identified as the main connection between the glacier drainage system and the marine ecosystem (How et al. 2017, Everett et al. 2018). These plumes, driven by glacier meltwater discharge, originate at the base of the tidewater glacier front and rise towards the surface due to the positive buoyancy of the meltwater relative to the surrounding seawater (Hartley \& Fisher 1936, Lydersen et al. 2014, Everett et al. 2018). During the process, the buoyant meltwater plume may entrain and transport nutrients and zooplankton to the surface, increasing their accessibility for surface-feeding predators, such as seabirds (Lydersen et al. 2014, Carroll et al. 2015, Nishizawa et al. 2020). Most importantly, the upwelling of the subglacial plume accelerates the along-fjord circulation of water masses and entrains seawater, from intermediate depths, of 10 to 30 times the original meltwater volume (Mortensen et al. 2013, Cowton et al. 2015, Meire et al. 2017, Halbach et al. 2019). Through its contribution to the plume's velocity and entrainment capacity, the subglacial discharge appears an important factor regulating the use of glacier fronts by marine wildlife (Lydersen et al. 2014, Urbański et al. 2017, Everett et al. 2018). Due to seasonal and interannual variations in temperature and precipitation, which affect the surface melt and snow accumulation, subglacial discharge from glaciers varies within and between years (van Pelt et al. 2019, Noël et al. 2020). At the daily scale, there seems to be a positive association between subglacial discharges and marine predator foraging activities at glacier fronts (Urbański et al. 2017, Everett et al. 2018). However, this association may vary from year to year (Stempniewicz et al. 2017, Dragańska-Deja et al. 2020). Although the discharge appears to be an essential mechanism for the entrainment and concentration of resources at the surface, the relative profitability of a glacier front should also depend on the abundance of the prey readily available in the water entrained by the plumes (Urbański et al. 2017) as well as the prey abundance in alternative foraging patches.

Prey abundances are highly heterogeneous in Arctic fjords, and their availability for consumers depends on the spatiotemporal nature of the process leading to their aggregation (e.g. Hunt et al. 1999, Weimerskirch 2007). Kongsfjorden is an open fjord, with no sill, on the west coast of Spitsbergen, the largest island of the Svalbard Archipelago $\left(78.91^{\circ} \mathrm{N}\right.$, $\left.11.93^{\circ} \mathrm{E}\right)$. This fjord is connected to the continental slope region through a submarine glacial trough, Kongsfjordrenna, and is thereby strongly influenced by the advection of Arctic waters from the coastal current and Atlantic waters from the West Spitsbergen Current (Fig. 1) (Svendsen et al. 2002, Hop et al. 2019). The interannual variation in advection of water masses to Kongsfjorden is modulated by the strength of the West Spitsbergen Current (Saloranta $\&$ Svendsen 2001) and the density front (i.e. geostrophic control) occurring at the mouth of the fjord, especially during winter and spring (Cottier et al. 2005, Tverberg et al. 2019). The density gradient has weakened in recent years, leading to an increase in the influence of warm Atlantic water masses on the fjord's ecosystem (Hop et al. 2019, Tverberg et al. 2019) and to a decline in sea ice cover (Pavlova et al. 2019). In addition, productivity in Kongsfjorden has also increased due to the advection of nutrients and Atlantic zooplankton into the fjord (Willis et al. 2006, Hegseth et al. 2019, Hop et al. 2019). The strength of such intrusions varies in time and modulates the composition and abundance of the pelagic community in the fjord (Willis et al. 2008, Hegseth et al. 2019, Hop et al. 2019, Tverberg et al. 2019). These interannual variations might therefore influence the amount of food resources available at the glacier-sea interface and, ultimately, their profitability as foraging sites for seabirds (Lydersen et al. 2014).

In this study, we investigated the interannual variation in glacier front use by black-legged kittiwakes Rissa tridactyla (hereafter kittiwakes) breeding in Kongsfjorden between 2014 and 2018. Kittiwakes are surface-feeding seabirds which forage on small fishes and zooplankton and are frequently observed at glacier fronts (Hartley \& Fisher 1936, Mehlum \& Gabrielsen 1993, Urbański et al. 2017, Nishizawa et al. 2020). By combining a multiyear dataset of GPS tracking, zooplankton biomass, and glacier dis- 


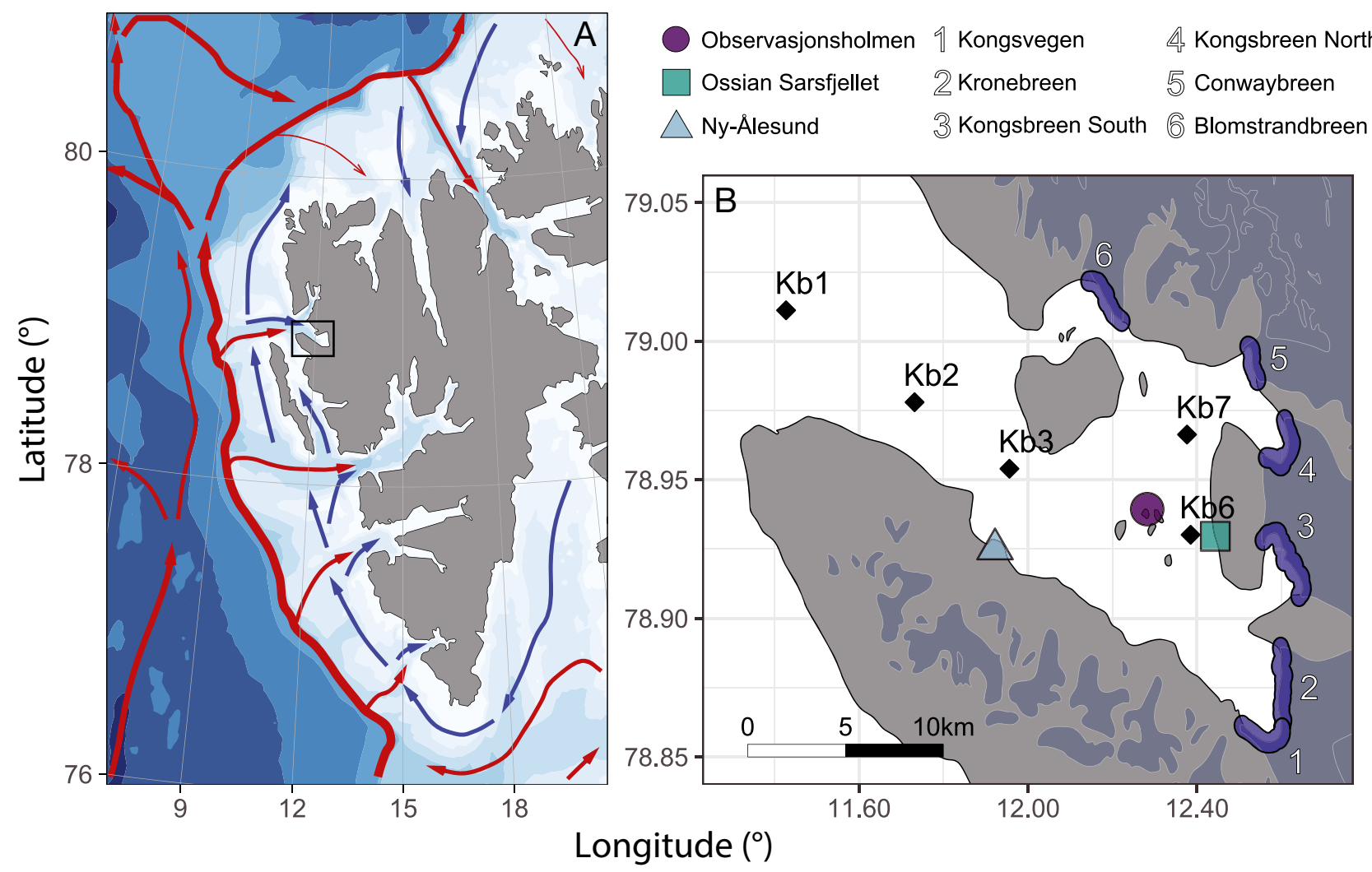

Fig. 1. (A) Distribution of Atlantic (red) and Arctic (blue) currents around western Svalbard; (B) Kongsfjorden area (black rectangle in [A]) showing the positions of the glacier fronts (2018; dark blue shaded areas numbered 1-6), black-legged kittiwake colonies (Observasjonsholmen and Ossian Sarsfjellet) studied between 2014 and 2018, and zooplankton sampling stations (black diamonds; Kb1-3, 6-7). Ny-Ålesund is also indicated. See Section 2.6 for map source details

charge estimates, we tested the hypothesis that the use of glacier fronts by the kittiwakes varies interannually as a function of the changing environmental conditions in the fjord. We predicted that the fronts would be used to a greater extent in years of higher discharge due to a higher entrainment capacity involving zooplankton (Carroll et al. 2015). Moreover, assuming that the zooplankton biomass in the fjord is representative of the food resource available at the fronts (Hop et al. 2019), we predicted that years with high prey biomass would be associated with a high level of front use by kittiwakes.

\section{MATERIALS AND METHODS}

\subsection{Study system}

The study was conducted on kittiwakes from 2 colonies in Kongsfjorden (Fig. 1): Ossian Sarsfjellet $\left(78.92^{\circ} \mathrm{N}, 12.44^{\circ} \mathrm{E}\right)$ and Observasjonsholmen $\left(78.93^{\circ} \mathrm{N}\right.$, $12.28^{\circ} \mathrm{E}$ ). In total, 6 tidewater glacier fronts are pres- ent in Kongsfjorden, and all are used by kittiwakes to some extent. Glaciers outside the fjord were not considered in our analyses because they are rarely used by seabirds nesting in Kongsfjorden (ca. $1 \%$ of the total tracked foraging trips during the study period; see Section 2.2 below).

\subsection{GPS tracking}

In total, 126 birds were caught using a noose pole and received a GPS logger over 5 yr (2014-2018; Table 1). Among them, $29 \%$ of individuals (21 in Ossian Sarsfjellet and 16 in Observasjonsholmen) were fitted twice with a logger in either the same or different years. Individuals were tracked during their incubation or chick-rearing period (respectively 49 and $51 \%$ of the birds). All captures (logger deployment and retrieval) were done between 10 June and 12 August (chick hatching generally occurs around mid-July; Burr et al. 2016). Three types of GPS loggers were deployed (i-gotU GT-120, Mobile Action; 
Table 1. Numbers of black-legged kittiwake foraging trips and individuals (in parentheses) tracked each year in Kongsfjorden, Svalbard. In total, 37 individuals were caught more than once (21 in Ossian Sarsfjellet and 16 in Observasjonsholmen). (-) no data

\begin{tabular}{|lcccccc|}
\hline Colony & 2014 & 2015 & 2016 & 2017 & 2018 & Total \\
\hline Ossian Sarsfjellet & $42(7)$ & $139(20)$ & $75(21)$ & $84(17)$ & $61(19)$ & $401(67)$ \\
Observasjonsholmen & - & - & $167(36)$ & $124(20)$ & $53(17)$ & $344(59)$ \\
\hline
\end{tabular}

between the complete and incomplete groups in their maximum distance travelled per trip; Mann-Whitney; $U=$ $312454, \mathrm{p}=0.625$ ). A total of $745 \mathrm{com}-$ plete foraging trips were recorded over the study period (Table 1 ; see also Supplementary information S5 for the distribution of raw tracks).
CatLog Gen1 and CatLog Gen2, www.mr-lee.com/ sc_supp.htm). Loggers weighed between 6.4 and $18.6 \mathrm{~g}(\bar{x} \pm \mathrm{SD}=14.3 \pm 3.9 \mathrm{~g})$, representing approximately 2 to $5 \%$ of each bird's mass (see Supplementary information S1 at www.int-res.com/articles/ suppl/m677p197_supp.pdf and Harris et al. [2020] for details on the GPS loggers). Loggers were attached to the back feathers of the birds using Tesa tape. We found no association between the relative weight of loggers (\%) and the level of use of glacier fronts (Supplementary information S1).

Kittiwakes were recaptured for logger retrieval 1 to $8 \mathrm{~d}$ after deployment $(\bar{x}=72.8 \mathrm{~h}$, range $=23.0-181.9 \mathrm{~h}$; see also Supplementary information S2 for details for each colony and year). Logger sampling resolution varied among breeding stages and years, ranging from $30 \mathrm{~s}$ to $10 \mathrm{~min}$. All tracks were therefore subsampled to obtain a standardized resolution of 10 min time lag between all consecutive locations. Locations were filtered by speed, using a maximum threshold of $80 \mathrm{~km} \mathrm{~h}^{-1}$ between successive locations (Paredes et al. 2012, Christensen-Dalsgaard et al. 2018). A foraging trip was defined as a bird leaving the colony for at least $50 \mathrm{~min}$ and then returning to the colony, which was determined as an area of $200 \mathrm{~m}$ radius around the colony centroid (i.e. representing the center of the sampled cliffs, being ca. 5-20 m long depending on the colony). These thresholds were evaluated using a bootstrap approach (see Supplementary information S3 for details of the procedure). Since kittiwakes are known to bathe in freshwater ponds (Coulson \& Macdonald 1962) and fetch nest materials on land, we filtered tracks based on the relative proportion of time spent over or on land to avoid retaining non-foraging trips. Based on the frequency distribution, all trips overlapping more than $50 \%$ with land were excluded from the analysis (Supplementary information S4). Trips were considered complete only if the first and last locations were at the colony, and all incomplete trips were removed from subsequent analyses. Filtering by the completeness of trips did not introduce a significant bias towards shorter trips (i.e. no significant difference

\subsection{Quantifying the use of glacier fronts}

The front area was spatially defined for each year as a zone within a distance of $400 \mathrm{~m}$ from the annually delimited glacier front lines (Fig. 1). The $400 \mathrm{~m}$ buffer radius was selected using sensitivity analyses (details in Supplementary information S6). During a given trip, a bird was considered to have used a glacier front if at least 2 successive (i.e. $10 \mathrm{~min}$ time intervals) GPS locations occurred at the same glacier front (Supplementary information S7 for details about how this threshold was selected).

\subsection{Glacier discharge}

We used the output from a coupled energy balance model and subsurface snow model to simulate the glacier runoff from the Kongsfjorden watershed (van Pelt et al. 2019). A complete account of the modeling environment and overall results is given in van Pelt et al. (2019). The model was first used to simulate the long-term glacier mass balance for the Kongsfjorden drainage basin (van Pelt \& Kohler 2015). It was then updated to include the seasonal snowpack of the non-glacierized section of the basin (Pramanik et al. 2018) and then finally expanded to cover all of Svalbard, on a $1 \mathrm{~km}$ grid (van Pelt et al. 2019); here, we use the output from the latter run. The mean daily runoff at each $1 \mathrm{~km}$ grid point equals the amount of surface melt and rain, which is not retained in the model snowpack due to refreezing or liquid water storage. We linearly interpolated the daily modeled runoff onto a $250 \mathrm{~m}$ grid and routed it to the appropriate glacier fronts along flow paths derived from the Matlab package TopoToolbox (Schwanghart \& Kuhn 2010). TopoToolbox calculates flow directions and drainage basins from any given potential surface; for subglacial drainage systems, the potential surface is commonly taken as the sum of the pressure potential from the ice overburden pressure, or a fraction thereof, and the elevation potential from the surface digital elevation model (DEM; e.g. Lindbäck et 
al. 2018). Accounting for ice pressure is important because subglacial drainage divides can be different from what surface elevations might otherwise imply; indeed, it seems likely that the drainage basin for Kronebreen is significantly larger than that derived from the surface DEM alone (Lindbäck et al. 2018). Routing is performed assuming that all runoff of surface melt and rain instantaneously reaches the front, i.e. there is no delay from the source to the glacier front. Delays would be in the order of hours to 1 or $2 \mathrm{~d}$ for the most distal grid points in the watersheds considered here.

Discharge time series calculations were performed for each of the 6 largest glacier fronts in Kongsfjorden. Daily glacier discharges were highly correlated (average Pearson's $r=0.93$, range $=0.81-0.99$ ) and thus were averaged to generate 1 single value per day for the entire fjord. To minimize the effect of temporal autocorrelation on our summary statistic, we calculated the area under the discharge curve (AUC) using the trapezoidal rule for integration (Matthews et al. 1990). To be comparable, we used an identical date interval for each time series, delimited by the first and the last days of bird tracking sessions for all years combined (i.e. 10 June and 12 August, respectively; see Supplementary information S8 for discharge distributions). We then divided the annual AUC values by the total number of days (i.e. $64 \mathrm{~d}$ ), leading to daily averages. We used the $\mathrm{R}$ package flux (version 0.3-0; Jurasinski et al. 2014) for the AUC calculation.

\subsection{Zooplankton biomass}

Zooplankton were collected as part of a long-term monitoring program in Kongsfjorden (Hop et al. 2019). In total, 5 stations along a transect distributed from the mouth to the inner fjord, with respective depths ranging from 189 to $35 \mathrm{~m}$ (Fig. 1), have been sampled every year between 13 and 31 July. Sampling was performed using a multiple plankton sampler (MultiNet type Midi, Hydro-Bios) with 5 closing nets with a mesh size of $200 \mu \mathrm{m}$ and an opening of $0.25 \mathrm{~m}^{2}$ (details in Hop et al. 2019). After collection, samples were preserved with hexamethylenetetramine-buffered formaldehyde at a final concentration of $4 \%$. Organisms were identified to the lowest possible taxonomic level and counted under a stereomicroscope equipped with an ocular micrometer, according to standard procedures (Postel et al. 2000). Small zooplankton (organisms with total body length $<5 \mathrm{~mm}$, including the juvenile stages of
Pteropoda, Euphausiacea, Amphipoda, and Chaetognatha) were identified and counted in subsamples obtained from the fixed sample volume by automatic pipette (approximately 500 individuals). Large zooplankton (organisms with body length $>5 \mathrm{~mm}$, including Pteropoda, Euphausiacea, Amphipoda, Decapoda, Chaetognatha) were sorted out and identified from the whole sample. The abundance (ind. $\mathrm{m}^{-3}$ ) of each species was converted to biomass estimates (mg dry mass $\mathrm{m}^{-3}$ ). The dry biomass conversion factors were gathered from published sources (see Appendix Table A1 in Hop et al. 2019). We further limited our analysis to the zooplankton species that are known to be prey for kittiwakes in Kongsfjorden (see Supplementary information S9 for species names; Vihtakari et al. 2018). The depth-averaged sums of all kittiwake prey by station were then averaged for each year to obtain a yearly seasonal biomass index value at the fjord level (hereafter termed zooplankton biomass; see Supplementary information S10), which we thereafter considered as a proxy of food availability to kittiwakes in a given year (e.g. LeBlanc et al. 2020). Since the buoyant discharge plume entrains a large amount of ambient seawater from its vicinity, promoting further the circulation of water masses in the fjord, we considered means of the 5 consistently sampled stations in the fjord to be representative of the zooplankton biomass that could be entrained at the glacier fronts (Zajaczkowski \& Legezynska 2001).

\subsection{Statistical analysis}

We modeled kittiwake use of glacier fronts using generalized linear mixed models with binomial error structure. We defined the response variable as binary (i.e. a bird used at least 1 glacier front area during its foraging trip or not). We tested the effects of 2 predictors on the use of glacier fronts: (1) fjordlevel discharge (i.e. runoff strength; calculated as $\mathrm{AUC}_{\text {; }}$ see Section 2.4), and (2) zooplankton biomass in the fjord. We further included the colony as a fixed effect to account for the average difference among colonies in their use of glacier fronts. We also fitted bird identity as a random intercept to control for individual-level repeated measures. The 2 predictors were further standardized (to mean 0 and SD 1) and had a low level of collinearity (variance inflation factor =1.66; Zuur et al. 2009). A non-parametric dispersion test over quantile residuals (from the DHARMa package, version 0.3.3.0; Hartig 2020) indicated no overdispersion in the full model $(p=0.314)$. Model 
selection was based on Akaike's information criterion (AIC). AICs were computed with the AICcmodavg package (version 2.3-1; Mazerolle 2020). The conditional $\mathrm{R}^{2}$, representing the variance explained by both the fixed and random effects, was reported as a measure of the model's goodness of fit (Barton 2019). To illustrate annual glacier front use by kittiwakes (and thus the adequacy of the models), we calculated the annual average glacier front use per colony using the following steps. We first calculated the proportion of the trips where fronts were used for each individual tracked in a given year. We then calculated the average annual and colony-specific use of glacier fronts using these individual proportions but weighted values using the number of trips recorded per individual. The $95 \%$ CIs for each average were computed by bootstrapping the individual proportions and associated weights along 999 iterations using the boot package (version 1.3-25; Canty \& Ripley 2020) and reported the 2.5 and $97.5 \%$ percentiles. All statistical analyses were performed using R (version 4.0.2; R Core Team 2020). Maps were made using the PlotSvalbard package (version 0.9.2, Vihtakari 2020) with land shapes from the Norwegian Polar Institute (S100; https://geodata.npolar.no/) and bathymetry generalized from the International Bathymetric Chart of the Arctic Ocean

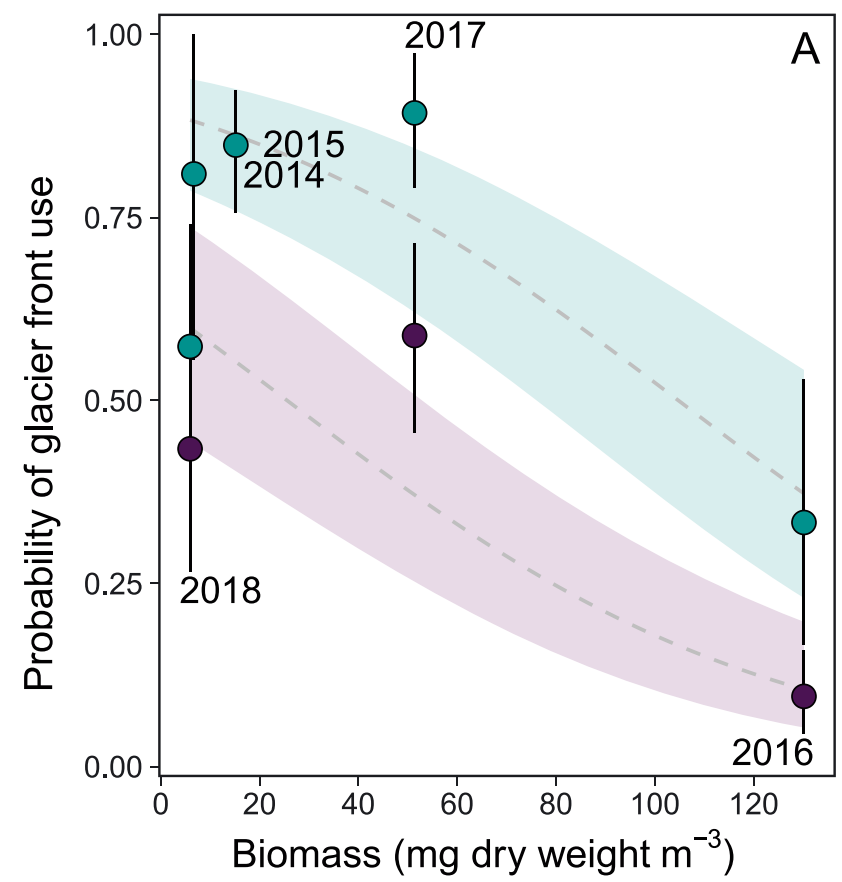

(IBCAO_V3_500m_RR) grid (Jakobsson et al. 2012). Ocean currents are from Vihtakari et al. (2019).

\section{RESULTS}

Over the study period (2014-2018), the annual average glacier discharge varied from 22.3 to $38.4 \mathrm{~m}^{3}$ $\mathrm{s}^{-1}$, and the zooplankton biomass in the fjord ranged from 5.93 to $130.20 \mathrm{mg}$ dry mass $\mathrm{m}^{-3}$. Of the 745 kittiwake foraging trips recorded during the study period (Table 1), 399 (54\%) were associated with the use of at least 1 of the glacier fronts in Kongsfjorden. However, foraging kittiwakes from both colonies displayed large interannual variation in their use of glacier fronts (Fig. 2). Birds from Ossian Sarsfjellet used glacier fronts on average $27 \%$ more than those from Observasjonsholmen (58 vs. $31 \%$ of the foraging trips, respectively; data from 2016 to 2018 when birds from both colonies were tracked). Although different in their relative magnitude, both colonies had parallel annual variations in their use of glacier fronts (Fig. 2). At the Ossian Sarsfjellet colony, where tracking data were obtained for 5 consecutive breeding seasons, 3 years $(2014,2015$, and 2017) were characterized by a relatively intensive use of glacier fronts, where individuals had on average ca. $86 \%$ of their

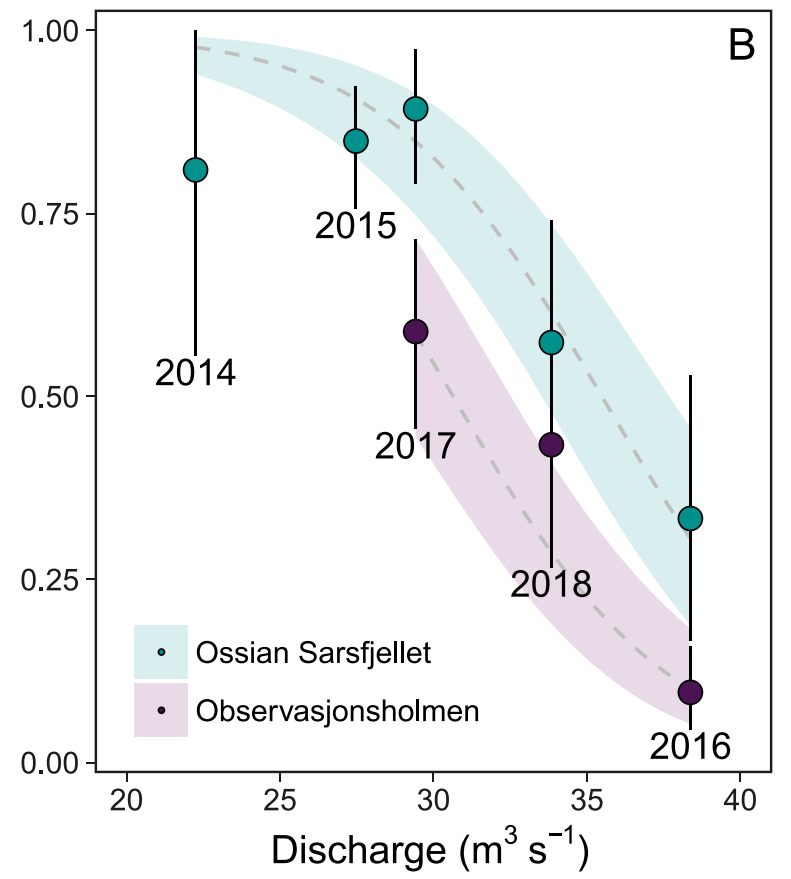

Fig. 2. Relationship between the use of glacier fronts by black-legged kittiwakes in Kongsfjorden, Svalbard, and (A) the summer zooplankton biomass in the fjord, and (B) the annual glacier discharge. Dashed lines and associated shaded areas depict the regression lines and $95 \%$ confidence intervals estimated from the binomial generalized linear mixed models, fitting individual identity as a random effect. Symbols represent the proportion of individual foraging trips that overlapped with front areas (weighted annual means) and their associated $95 \%$ bootstrap CIs 
foraging trips that overlapped a front area compared to $57 \%(95 \% \mathrm{CI}=39-74 \%)$ in 2018 and $33 \%(95 \%$ CI $=18-51 \%$ ) in 2016 (Fig. 2).

When considered independently, both the zooplankton biomass in the fjord and the annual glacier discharge level were negatively correlated to the glacier front use (Fig. 2). The relationships did not appear to differ between incubation and chick-rearing periods (see Supplementary information S11). Based on the AIC ranking, the model combining the 2 predictors received similar support $(\triangle \mathrm{AIC}<2)$ as the model involving the discharge level only, while the model involving only the zooplankton biomass predictor ranked poorly (Table 2). This suggests that after controlling for the effect of glacier discharge, the effect of zooplankton biomass on the use of glacier fronts by kittiwakes was still negative but negligible (Table 2).

\section{DISCUSSION}

By combining 5 yr of bird movement data, zooplankton monitoring, and glacier discharge modeling, our study confirmed that kittiwakes breeding in Kongsfjorden used glacier fronts in all years but to a varying degree depending on the environmental conditions. Our results suggest that glacier fronts are not stable foraging hotspots for kittiwakes and are likely not offering consistently profitable foraging opportunities for breeding marine birds. Annual variation in the use of the glacier fronts as foraging areas was expected to be linked to (1) the subglacial discharge, since greater discharge at the front was expected to lead to greater entrainment and transport of zooplankton to the surface; and (2) the zooplankton biomass level in the fjord, which was assumed to be representative of the food resource availability at the fronts and hence to modulate their profitability. Contrary to our predictions, however, these 2 predictors showed a negative relationship with the use of the glacier fronts by the kittiwakes in Kongsfjorden, where the zooplankton biomass in the fjord had a much weaker explanatory power than the discharge.

\subsection{Interannual variation in the use of glacier fronts}

The magnitude of interannual variation in glacier front use by kittiwakes observed in our study is concordant with studies reporting annual changes in the abundance or occurrence of various marine predators at or near glacier fronts. Stempniewicz et al. (2017) observed a drastic difference in seabird abundance at glacier fronts between 2 subsequent years (2014-2015) in the glacial bay of Burgerbukta, Hornsund (Svalbard), which was associated with a marked change in summer weather conditions. The number of kittiwakes and little auks Alle alle increased in the fjord during the windier year, suggesting that the glacial bays and glacier fronts could act as an alternative foraging habitat when adverse weather conditions occur offshore (Stempniewicz et al. 2017). Using time-lapse cameras, another study on kittiwakes in Kongsfjorden observed that the abundance of birds at one specific front (i.e. Kronebreen) was lower in 2014 than in 2015 (H. Strøm \& S. Descamps unpubl. data). In mammals, the occurrence of ringed seals Pusa hispida within $5 \mathrm{~km}$ of glacier fronts increased between 1996 and 2016 following the Atlantification of water masses in Svalbard (Hamilton et al. 2016, 2019, Tverberg et al. 2019). Redistribution of the main prey of the seals, the polar cod Boreogadus saida, which tends to congregate near the fronts of tidewater glaciers, likely explains such patterns (Hamilton et al. 2019). Within the same study period, white whales Delphinapterus leucas showed the opposite trend, shifting their foraging

Table 2. Model selection for the probability to use glacier fronts by foraging black-legged kittiwakes in Svalbard. Results are from binomial generalized linear mixed models fitting individual identity as a random effect. The estimate of the glacier discharge and zooplankton biomass effects along with their $95 \%$ CIs are given. $K$ : number of parameters of each model (including the random effect); AIC: Akaike's information criterion; $\triangle \mathrm{AIC}$ : difference in AIC units compared to the model with lowest AIC; Cond. $\mathrm{R}^{2}$ : conditional $\mathrm{R}^{2}$; (-) not estimated

\begin{tabular}{|lcccccc|}
\hline Model & $K$ & AIC & $\Delta$ AIC & Discharge $(95 \%$ CI) & Biomass (95\% CI) & Cond. R \\
\hline Discharge + Biomass + Colony & 5 & 709.27 & 0.00 & $-1.17(-1.65$ to -0.71$)$ & $-0.33(-0.75$ to 0.08$)$ & 0.59 \\
Discharge + Colony & 4 & 709.78 & 0.51 & $-1.41(-1.80$ to -1.07$)$ & - & 0.59 \\
Biomass + Colony & 4 & 732.35 & 23.08 & - & $-1.04(-1.38$ to -0.74$)$ & 0.57 \\
Colony & 3 & 776.15 & 66.87 & - & - & 0.57 \\
Null model & 2 & 800.77 & 91.50 & - & - \\
\hline
\end{tabular}


grounds away from glacier fronts, likely as an adjustment to the distribution of alternative Atlantic prey (Hamilton et al. 2019). The interannual variation in the use of glacier fronts by marine consumers thus appears to be species specific and is likely modulated by weather conditions, prey availability, and distribution.

Optimal foraging theory predicts that individuals should use and spend more time in higher-profitability habitat patches (MacArthur \& Pianka 1966, Schoener 1971). The relative foraging profitability of glacier fronts compared to other relevant habitats is thus expected to drive the annual variation in space use by marine predators. The cost-benefit ratio associated with glacier front use is likely shaped by numerous factors like the local prey abundance at the front and the number of sympatric competitors as well as the prey abundance in alternative foraging habitats (e.g. fjord, open sea). Hence, selection of the glacier fronts as foraging habitat might not be modulated solely by conditions near or at the front but also by environmental conditions on a larger spatial scale.

\subsection{Glacier front use and glacier discharge}

Contrary to our prediction, the average glacier discharge was negatively related to the probability of glacier front use by breeding kittiwakes. Assuming that the result is neither spurious nor confounded by some other parameters, it may indicate that the profitability of using glacier fronts for kittiwakes decreases at high plume velocity. Two direct mechanisms may explain this unexpected result: (1) the direct negative effect of surface current on kittiwake foraging at the front, and (2) the negative effect of turbidity on prey detection. Greater discharge level can lead to stronger down-fjord surface currents (Cowton et al. 2015), which can push kittiwakes off the protruding site and therefore increase the energetic costs of foraging at the front (i.e. as birds would rely to a greater extent on short flights to return to the foraging patch). However, flight costs are low in kittiwakes relative to other foraging behaviors (Jodice et al. 2003), and the cost of flying back to the protruding site should be negligible. Alternatively, a greater discharge leads to more sediment transport to the glacier, thus increasing the turbidity of the fjord water (Schild et al. 2017), potentially restricting the ability of foraging birds to detect prey (Stempniewicz et al. 2013). Contrary to this view, however, Nishizawa et al. (2020) observed that the turbidity level in a glacial fjord of northwestern Greenland was positively linked to the density of foraging kittiwakes. This association was explained by the high abundance of nearsurface zooplankton in the vicinity of the turbid subglacial plume (Nishizawa et al. 2020). Hence, we believe that such negative direct effects of discharge level on birds are unlikely to explain the observed pattern. This pattern likely reflects more complex mechanisms linking discharge level and bird foraging behavior (see Section 4.3 below).

Varying responses of marine wildlife foraging behavior to changes in glacier discharge level have been reported in the few studies dealing with this topic. Using hourly time-lapse camera observations, kittiwake abundance was positively related to the level of discharge at the Kronebreen's front in Kongsfjorden, but the effect was weak and detected in only 1 of 2 yr (H. Strøm \& S. Descamps unpubl. data). Similarly, using suspended matter concentration as a proxy for discharge intensity, Urbański et al. (2017) showed that individual kittiwake distributions were correlated with turbid surface water plume locations on a daily scale. At the same scale, the use of surface mass balance models showed that the use of fronts by ringed seals was positively linked to the strength of glacier discharge in Kongsfjorden (Everett et al. 2018). On the other hand, a study conducted in western Greenland combining multiple variables characterizing glacier front dynamics and structure found no apparent effect of the yearly average subglacial discharge level on habitat selection processes by narwhals Monodon monoceros (Laidre et al. 2016). While evidence suggests that higher daily discharge levels could increase the use of glacier fronts by marine wildlife within a given year, these results underline the importance of scale when investigating the mechanism linking discharge dynamics to the use of glacier fronts by marine predators.

\subsection{Zooplankton biomass in the fjord}

Our results suggest a negative association between annual zooplankton biomass in the fjord and the likelihood of glacier front use by kittiwakes. The use of the fronts was the lowest in 2016, which was the year characterized by the highest zooplankton biomass in the fjord in our study period. This high level of biomass may have increased the abundance of fishes in the fjord (e.g. LeBlanc et al. 2020), offering highly profitable foraging opportunities close to the colonies. Interestingly, stomach contents showed that kittiwakes breeding in Kongsfjorden fed mainly on fish in 2016, compared to 2014 and 2015 when zoo- 
plankton was dominant in their diet (Vihtakari et al. 2018). When fish of a suitable size range are available, kittiwakes will presumably select fish over zooplankton due to their higher energy content (Hop \& Gjøsæter 2013). Hence, the availability of abundant and highly profitable prey in alternative foraging patches in 2016 may have driven the apparent negative effect of zooplankton biomass on glacier front use.

These results suggest that such relationships might be more complex than expected and are likely nonlinear (see also Grémillet et al. 2015). This remains speculative, and longer time series including additional data on other kittiwake prey, such as polar cod and capelin Mallotus villosus biomass, are needed to determine their relative availability in Kongsfjorden. We nonetheless suggest that the relative profitability of glacier fronts as foraging sites could be better described as a quadratic function of the zooplankton biomass in the fjord (see the hypothetical scenario in Fig. 3A). Up to a certain threshold, an increase in zooplankton biomass in the fjord could increase food availability at the fronts, thus increasing their profitability and the level of glacier front use by birds. However, above a given threshold of zooplankton biomass in the fjord, the relationship could then become negative due to the emergence of additional profitable foraging opportunities elsewhere in the fjord. In such years of very high zooplankton biomass, food may be available virtually everywhere, and there would be no specific benefit in using glacier fronts with potentially high competition.

\subsection{Interacting effects between discharge and biomass density}

The profitability of tidewater glacier fronts in a given year is expected to be modulated by prey availability in the fjord, which could thereafter be mechanically upwelled by the plume towards the surface (Zajaczkowski \& Legezynska 2001). The effect of the annual discharge level should thus be modulated by the zooplankton biomass in the fjord, and such interacting effects could be more important than expected in our study system. Unfortunately, we could not test such an effect due to the limited number of years involved in our study. However, insight from our results constitutes a basis for further hypothesis development.
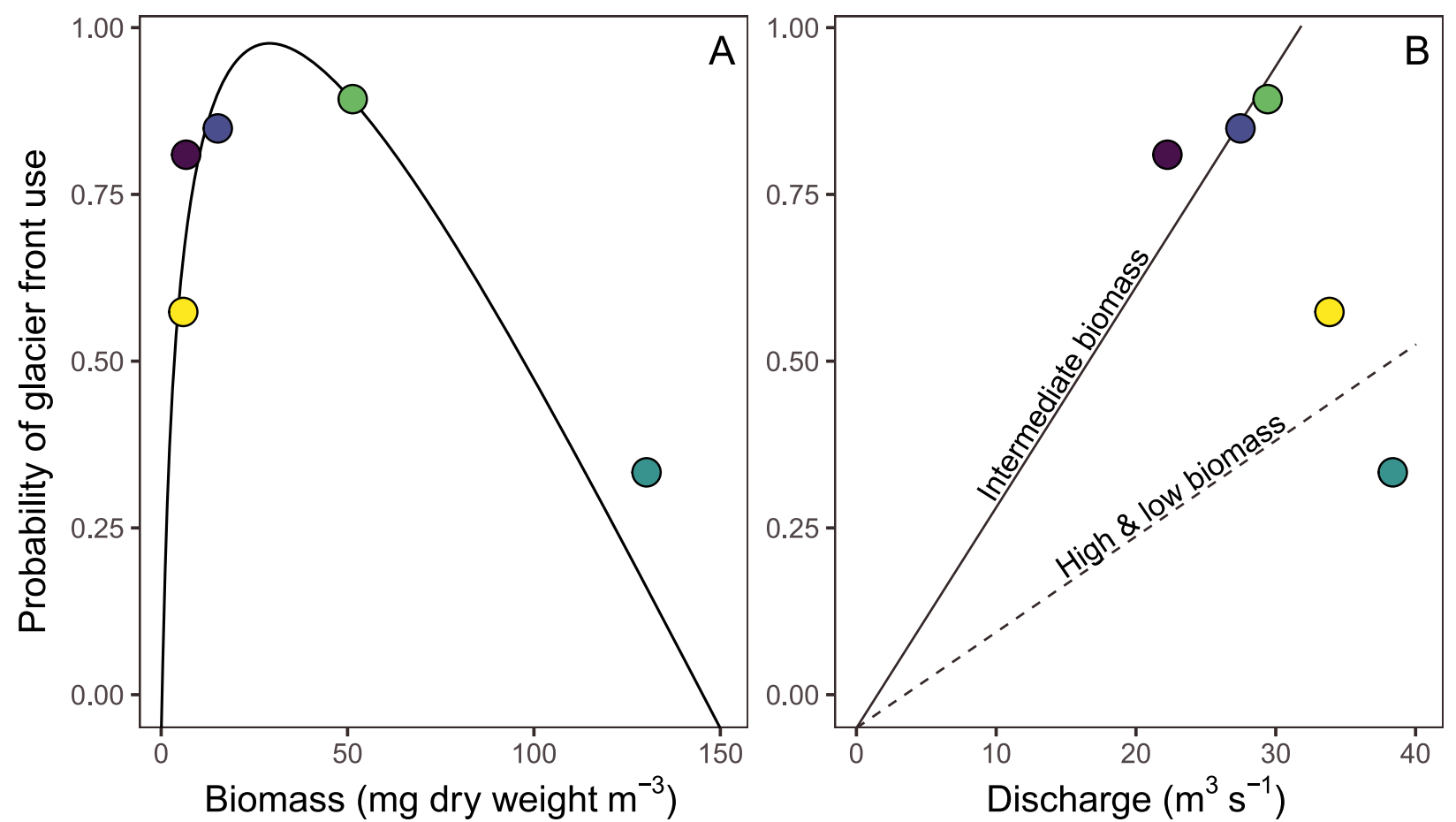

Fig. 3. Hypothetical relationships between the use of glacier fronts by foraging kittiwakes and (A) the zooplankton biomass in Kongsfjorden, Svalbard, and (B) the annual glacier discharge for different levels of summer zooplankton biomass in the fjord. The shapes of the depicted functions are hypothetical. Circles represent the average proportion of individual foraging trips that overlapped with front areas for birds breeding at the Ossian Sarsfjellet colony and are based on tracking data obtained over 5 yr (2014 = purple; $2015=$ dark blue; $2016=$ dark green; $2017=$ light green; and $2018=$ yellow $)$ 
Conceptualizing the interactive effect between zooplankton biomass and discharge level on the use of the fronts could indeed offer an alternative view of our results (see theoretical model proposed in Fig. 3B). In that context, birds might respond to the discharge level as a function of the overall zooplankton biomass in the fjord. As such, the strength of the response to changes in discharge level could be modulated by zooplankton biomass. With a low supply of zooplankton at the front (i.e. at low zooplankton biomass), an increase in freshwater discharge should have a limited impact on prey availability at the front, which would only result in a slight increase in front profitability and, thus, use. At intermediate levels of biomass, an increase in discharge level should have a strong effect on the use of the glacier front, as more prey would be entrained and transported in the plume while the prey availability would still be limited in the rest of the fjord. On the other hand, at a very high level of zooplankton biomass in the fjord, prey could be available at high densities throughout the fjord, offering alternative and more profitable foraging habitat patches than at the glacier fronts. In such cases, variation in discharge level would have limited impacts on front use. Considering our results and hypothetical models, the discharge level and associated entrainment rate may, as previously suggested, strongly influence the use of glacier fronts by consumers but only under some circumstances (i.e. when there are enough food resources to supply the plume and when alternative foraging patches are not overly abundant in the vicinity of the fronts).

\subsection{Future research}

Tidewater glaciers are currently retreating in Svalbard (Kohler et al. 2007). Once a glacier terminus is above the sea level, the plume's entrainment capacity becomes greatly reduced, decreasing in tandem with prey availability at the front (Hopwood et al. 2018, Halbach et al. 2019). How such a retreat will affect the fitness of wildlife foraging at the front remains poorly known. Although glacier fronts may provide high-quality marine foraging habitats, the level at which different species use and rely on these sites for successful reproduction is not resolved. Documenting the heterogeneity level in the use of glacier fronts within species thus appears necessary for more accurate predictions and assessments of the differential behavioral and demographic responses to the potential loss of these foraging hotspots.
Acknowledgements. The study was performed under permit nos. 6439, 8602, and 15503 from the Norwegian Food Safety Authority (in charge of animal welfare in Norway) and a permit from the Governor of Svalbard for research program 361. The study was funded by the Fonds de recherche du Québec-Nature et technologies (FRQNT), Natural Sciences and Engineering Research Council of Canada (NSERC), MITACS (Globalink), the Norwegian Polar Institute (from the former Centre for Ice, Climate and Ecosystem and MOSJ program, www.mosj.no), the SEAPOP program (www. seapop.no), and the Polish-Norwegian Research Program operated by the National Centre for Research and Development (under Norwegian Financial Mechanism 2009-2014, in the frame of project contract no. POL-NOR/199377/91/ 2014 [GLAERE]). We thank Maite Cerezo Araujo, Delphin Ruche, and Saga Svavarsdóttir and the logistic department of the Norwegian Polar Institute for their support in the field. We also thank Christian Lydersen, Andrew D. Lowther, and Sébastien Moreau for fruitful discussions and Kyle Elliott and Connie Sullivan for their comments on the earlier version of the manuscript.

\section{LITERATURE CITED}

AMAP (Arctic Monitoring and Assessment Programme) (2017) Snow, water, ice and permafrost in the Arctic (SWIPA) 2017. Www.amap.no/documents/doc/SnowWater-Ice-and-Permafrost-in-the-Arctic-SWIPA-2017/ 1610

Barton K (2019) MuMIn: multi-model inference. R package version 1.43.15. https://CRAN.R-project.org/package= MuMIn

* Burr ZM, Varpe Ø, Anker-Nilssen T, Erikstad KE and others (2016) Later at higher latitudes: large-scale variability in seabird breeding timing and synchronicity. Ecosphere 7 : e01283

Canty A, Ripley B (2020) Boot: bootstrap R (S-Plus) functions. R package version 1.3-25. https://CRAN.R-project. org/web/packages/boot/index.html

Carroll D, Sutherland DA, Shroyer EL, Nash JD, Catania GA, Stearns LA (2015) Modeling turbulent subglacial meltwater plumes: implications for fjord-scale buoyancydriven circulation. J Phys Oceanogr 45:2169-2185

* Christensen-Dalsgaard S, May R, Lorentsen SH (2018) Taking a trip to the shelf: behavioral decisions are mediated by the proximity to foraging habitats in the black-legged kittiwake. Ecol Evol 8:866-878

Cottier F, Tverberg V, Inall M, Svendsen H, Nilsen F, Griffiths C (2005) Water mass modification in an Arctic fjord through cross-shelf exchange: the seasonal hydrography of Kongsfjorden, Svalbard. J Geophys Res Oceans 110:1-18

Coulson JC, Macdonald A (1962) Recent changes in the habits of the kittiwake. Br Birds 55:171-177

* Cowton T, Slater D, Sole A, Goldberg D, Nienow P (2015) Modeling the impact of glacial runoff on fjord circulation and submarine melt rate using a new subgrid-scale parameterization for glacial plumes. J Geophys Res Oceans 120:796-812

* Dalpadado P, Hop H, Rønning J, Pavlov V and others (2016) Distribution and abundance of euphausiids and pelagic amphipods in Kongsfjorden, Isfjorden and Rijpfjorden (Svalbard) and changes in their relative importance as key prey in a warming marine ecosystem. Polar Biol 39: 1765-1784 
Dragańska-Deja K, Błaszczyk M, Deja K, Wesławski JM, Rodak J (2020) Tidewater glaciers as feeding spots for the black-legged kittiwake (Rissa tridactyla): a citizen science approach. Pol Polar Res 41:69-93

Everett A, Kohler J, Sundfjord A, Kovacs KM and others (2018) Subglacial discharge plume behaviour revealed by CTD-instrumented ringed seals. Sci Rep 8:13467

G Grémillet D, Fort J, Amélineau F, Zakharova E, Le Bot T, Sala E, Gavrilo M (2015) Arctic warming: nonlinear impacts of sea-ice and glacier melt on seabird foraging. Glob Change Biol 21:1116-1123

*Halbach L, Vihtakari M, Duarte P, Everett A and others (2019) Tidewater glaciers and bedrock characteristics control the phytoplankton growth environment in a fjord in the Arctic. Front Mar Sci 6:254

*Hamilton CD, Lydersen C, Ims RA, Kovacs KM (2016) Coastal habitat use by ringed seals Pusa hispida following a regional sea-ice collapse: importance of glacial refugia in a changing Arctic. Mar Ecol Prog Ser 545: 261-277

Hamilton CD, Kovacs KM, Ims RA, Aars J, Lydersen C (2017) An Arctic predator-prey system in flux: climate change impacts on coastal space use by polar bears and ringed seals. J Anim Ecol 86:1054-1064

Hamilton CD, Vacquié-Garcia J, Kovacs KM, Ims RA, Kohler J, Lydersen C (2019) Contrasting changes in space use induced by climate change in two Arctic marine mammal species. Biol Lett 15:20180834

Harris SM, Descamps S, Sneddon LU, Bertrand P, Chastel O, Patrick SC (2020) Personality predicts foraging site fidelity and trip repeatability in a marine predator. $\mathrm{J}$ Anim Ecol 89:68-79

Hartig F (2020) Residual diagnostics for hierarchical (multilevel/mixed) regression models. $\mathrm{R}$ package version 0.3 . 3.0. https://CRAN.R-project.org/package=DHARMa

Hartley CH, Fisher J (1936) The marine foods of birds in an inland fjord region in west Spitsbergen: part 2. Birds. J Anim Ecol 5:370-389

Hegseth EN, Assmy P, Wiktor JJ, Kristiansen S and others (2019) Phytoplankton seasonal dynamics in Kongsfjorden, Svalbard and the adjacent shelf. In: Hop H, Wiencke C (eds) The ecosystem of Kongsfjorden, Svalbard. Advances in Polar Ecology, Vol 2. Springer, Cham, p 173-227

Hop H, Gjøsæter H (2013) Polar cod (Boreogadus saida) and capelin (Mallotus villosus) as key species in marine food webs of the Arctic and the Barents Sea. Mar Biol Res 9: 878-894

Hop H, Wold A, Vihtakari M, Daase M and others (2019) Zooplankton in Kongsfjorden (1996-2016) in relation to climate change. In: Hop H, Wiencke C (eds) The ecosystem of Kongsfjorden, Svalbard. Advances in Polar Ecology, Vol 2. Springer, Cham, p 229-300

Hopwood MJ, Carroll D, Browning TJ, Meire L, Mortensen J, Krisch S, Achterberg EP (2018) Non-linear response of summertime marine productivity to increased meltwater discharge around Greenland. Nat Commun 9:3256

*Hopwood MJ, Carroll D, Dunse T, Hodson A and others (2020) Review article: How does glacier discharge affect marine biogeochemistry and primary production in the Arctic? Cryosphere 14:1347-1383

How P, Benn DI, Hulton NRJ, Hubbard B and others (2017) Rapidly changing subglacial hydrological pathways at a tidewater glacier revealed through simultaneous observations of water pressure, supraglacial lakes, meltwater plumes and surface velocities. Cryosphere 11:2691-2710
Hunt GL Jr, Mehlum F, Russell RW, Irons D, Decker MB, Becker H (1999) Physical processes, prey abundance, and the foraging ecology of seabirds. In: Adams NJ, Slotow RH (eds) Proc 22 Int Ornithol Congr, Durban. BirdLife South Africa, Johannesburg, p 2040-2056

Jakobsson M, Mayer L, Coakley B, Dowdeswell JA and others (2012) The International Bathymetric Chart of the Arctic Ocean (IBCAO) version 3.0. Geophys Res Lett 39: L12609

Jodice PGR, Roby DD, Suryan RM, Irons DB, Kaufman AM, Turco KR, Visser GH (2003) Variation in energy expenditure among black-legged kittiwakes: effects of activityspecific metabolic rates and activity budgets. Physiol Biochem Zool 76:375-388

Jurasinski G, Koebsch F, Guenther A, Beetz S (2014) Flux: flux rate calculation from dynamic closed chamber measurements. R package version 0.3-0. https://CRAN.R-project.org/package=flux

Kohler J, James TD, Murray T, Nuth C and others (2007) Acceleration in thinning rate on western Svalbard glaciers. Geophys Res Lett 34:L18502

* Laidre KL, Moon T, Hauser DDW, McGovern R, Heide-Jørgensen MP, Dietz R, Hudson B (2016) Use of glacial fronts by narwhals (Monodon monoceros) in west Greenland. Biol Lett 12:20160457

LeBlanc M, Geoffroy M, Bouchard C, Gauthier S, Majewski A, Reist JD, Fortier L (2020) Pelagic production and the recruitment of juvenile polar cod Boreogadus saida in Canadian Arctic seas. Polar Biol 43:1043-1054

* Lindbäck K, Kohler J, Pettersson R, Nuth C and others (2018) Subglacial topography, ice thickness, and bathymetry of Kongsfjorden, northwestern Svalbard. Earth Syst Sci Data 10:1769-1781

* Lydersen C, Assmy P, Falk-Petersen S, Kohler J and others (2014) The importance of tidewater glaciers for marine mammals and seabirds in Svalbard, Norway. J Mar Syst 129:452-471

*MacArthur RH, Pianka ER (1966) On optimal use of a patchy environment. Am Nat 100:603-609

*Matthews JNS, Altman DG, Campbell MJ, Royston P (1990) Analysis of serial measurements in medical research. BMJ 300:230-235

Mazerolle MJ (2020) AICcmodavg: model selection and multimodel inference based on (Q)AIC(c). R package version 2.3-1. https://CRAN.R-project.org/package= AICcmodavg

* Mehlum F, Gabrielsen GW (1993) The diet of high-Arctic seabirds in coastal and ice-covered, pelagic areas near the Svalbard archipelago. Polar Res 12:1-20

*Meire L, Mortensen J, Meire P, Juul-Pedersen T and others (2017) Marine-terminating glaciers sustain high productivity in Greenland fjords. Glob Change Biol 23: 5344-5357

* Mortensen J, Bendtsen J, Motyka RJ, Lennert K, Truffer M, Fahnestock M, Rysgaard S (2013) On the seasonal freshwater stratification in the proximity of fast-flowing tidewater outlet glaciers in a sub-Arctic sill fjord. J Geophys Res Oceans 118:1382-1395

Nishizawa B, Kanna N, Abe Y, Ohashi Y and others (2020) Contrasting assemblages of seabirds in the subglacial meltwater plume and oceanic water of Bowdoin Fjord, northwestern Greenland. ICES J Mar Sci 77:711-720

*Noël B, Jakobs CL, van Pelt WJJ, Lhermitte S and others (2020) Low elevation of Svalbard glaciers drives high mass loss variability. Nat Commun 11:4597 
Paredes R, Harding AMA, Irons DB, Roby DD and others (2012) Proximity to multiple foraging habitats enhances seabirds' resilience to local food shortages. Mar Ecol Prog Ser 471:253-269

Pavlova O, Gerland S, Hop H (2019) Changes in sea-ice extent and thickness in Kongsfjorden, Svalbard (2003-2016). In: Hop H, Wiencke C (eds) The ecosystem of Kongsfjorden, Svalbard. Advances in Polar Ecology, Vol 2. Springer, Cham, p 105-136

Post E, Bhatt US, Bitz CM, Brodie JF and others (2013) Ecological consequences of sea-ice decline. Science 341: 519-524

Postel L, Fock H, Hagen W (2000) Biomass and abundance. In: Harris R, Wiebe P, Lens J, Skjoldal HR, Huntley M (eds) ICES zooplankton methodology manual. Academic Press, San Diego, CA, p 83-192

"Pramanik A, van Pelt W, Kohler J, Schuler TV (2018) Simulating climatic mass balance, seasonal snow development and associated freshwater runoff in the Kongsfjord basin, Svalbard (1980-2016). J Glaciol 64:943-956

R Core Team (2020) R: a language and environment for statistical computing. R Foundation for Statistical Computing, Vienna. https://www.R-project.org/

Saloranta TM, Svendsen H (2001) Across the Arctic front west of Spitsbergen: high-resolution CTD sections from 1998-2000. Polar Res 20:177-184

Schild KM, Hawley RL, Chipman JW, Benn DI (2017) Quantifying suspended sediment concentration in subglacial sediment plumes discharging from two Svalbard tidewater glaciers using landsat-8 and in situ measurements. Int J Remote Sens 38:6865-6881

Schoener TW (1971) Theory of feeding strategies. Annu Rev Ecol Syst 2:369-404

Schwanghart W, Kuhn NJ (2010) TopoToolbox: a set of Matlab functions for topographic analysis. Environ Model Softw 25:770-781

Stempniewicz L, Darecki M, Trudnowska E, BłachowiakSamołyk K and others (2013) Visual prey availability and distribution of foraging little auks (Alle alle) in the shelf waters of west Spitsbergen. Polar Biol 36:949-955

Stempniewicz L, Goc M, Kidawa D, Urbański J, Hadwiczak M, Zwolicki A (2017) Marine birds and mammals foraging in the rapidly deglaciating Arctic fjord-numbers, distribution and habitat preferences. Clim Change 140: 533-548

Stempniewicz L, Weydmann-Zwolicka A, Strzelewicz A, Goc M and others (2021) Advection of Atlantic water masses influences seabird community foraging in a highArctic fjord. Prog Oceanogr 193:102549

Editorial responsibility: Lisa T. Ballance,

Newport, Oregon, USA

Reviewed by: 3 anonymous referees
Stott FC (1936) The marine foods of birds in an inland fjord region in west Spitsbergen: part 1. Plankton and in shore benthos. J Anim Ecol 5:356-369

Svendsen H, Beszczynska-Møller A, Hagen JO, Lefauconnier B and others (2002) The physical environment of Kongsfjorden-Krossfjorden, an Arctic fjord system in Svalbard. Polar Res 21:133-166

Tverberg V, Skogseth R, Cottier F, Sundfjord A and others (2019) The Kongsfjorden transect: seasonal and interannual variability in hydrography. In: Hop H, Wiencke C (eds) The ecosystem of Kongsfjorden, Svalbard. Advances in Polar Ecology, Vol 2. Springer, Cham, p 49-104

*Urbański JA, Stempniewicz L, WAsławski JM, DragańskaDeja K, Wochna A, Goc M, Iliszko L (2017) Subglacial discharges create fluctuating foraging hotspots for seabirds in tidewater glacier bays. Sci Rep 7:43999

*van Pelt W, Kohler J (2015) Modelling the long-term mass balance and firn evolution of glaciers around Kongsfjorden, Svalbard. J Glaciol 61:731-744

* van Pelt W, Pohjola V, Pettersson R, Marchenko S and others (2019) A long-term dataset of climatic mass balance, snow conditions and runoff in Svalbard (1957-2018). Cryosphere 13:2259-2280

Vihtakari M (2020) PlotSvalbard: plot research data from Svalbard on maps. R package version 0.9.2. https:// github.com/MikkoVihtakari/PlotSvalbard

*Vihtakari M, Welcker J, Moe B, Chastel O and others (2018) Black-legged kittiwakes as messengers of Atlantification in the Arctic. Sci Rep 8:1178

Vihtakari M, Sundfjord A, de Steur L (2019) Barents Sea ocean-current arrows modified from Eriksen et al. (2018). Norwegian Polar Institute and Institute of Marine Research. https://github.com/MikkoVihtakari/BarentsSea-currents (accessed 1 November, 2020)

* Weimerskirch H (2007) Are seabirds foraging for unpredictable resources? Deep Sea Res II 54:211-223

Willis K, Cottier F, Kwasniewski S, Wold A, Falk-Petersen S (2006) The influence of advection on zooplankton community composition in an Arctic fjord (Kongsfjorden, Svalbard). J Mar Syst 61:39-54

Willis KJ, Cottier FR, Kwaśniewski S (2008) Impact of warm water advection on the winter zooplankton community in an Arctic fjord. Polar Biol 31:475-481

Zajaczkowski M, Legezynska J (2001) Estimation of zooplankton mortality caused by Arctic glacial outflow. Oceanologia 43:341-351

Zuur AF, Ieno EN, Walker N, Saveliev AA, Smith GM (2009) Mixed effects models and extensions in ecology with R. Springer, New York, NY

Submitted: February 3, 2021

Accepted: August 9, 2021

Proofs received from author(s): October 22, 2021 